\title{
Nieznane losy znanej książki. O ponownym odkrywaniu klasycznego utworu Heinricha Hoffmanna
}

\author{
Dybiec-Gajer, J. (2017). Złota różdżka - od książki dla dzieci \\ po dreszczowiec raczej dla dorosłych. Kraków: Tertium.
}

\section{Abstrakt:}

W artykule recenzyjnym omówiono książkę Joanny Dybiec-Gajer pt. Złota różḋka - od książki dla dzieci po dreszczowiec raczej dla dorosłych (2017). W tekście zaprezentowano strukturę, metodologię i najważniejsze tezy monografii dotyczącej klasycznego już utworu Heinricha Hoffmanna (1845) oraz wskazano na oryginalne i wartościowe ustalenia badaczki, udowadniające sens ponownego odkrywania dzieł należących do kanonu kulturowego. W artykule zasygnalizowano również produktywność tworzenia mikrohistorii utworu literackiego z uwzględnieniem licznych kontekstów jego funkcjonowania i odniesiono się do rozważań Dybiec-Gajer na temat sposobów pisania tekstu (m.in. struktura, konwencja gatunkowa, mechanizmy adaptacyjne) oraz sposobów jego czytania (m.in. interpretacja, recepcja), co jest szczególnie interesujące w kontekście relacji między niemieckim Struwwelpeterem a rosyjskim Stiopką-Rastriopką (1849) i polską Złotą różdżkq (ok. 1858).

\section{Słowa kluczowe:}

adaptacja, analiza punktów krytycznych, Heinrich Hoffmann, Joanna Dybiec-Gajer, literatura XIX wieku, literatura dziecięca, literatura niemiecka, przekład, recepcja, Stiopka-Rastriopka, Struwwelpeter, struwwelpetriady, Złota różḋka

* Kamila Kowalczyk - dr, pracuje w Instytucie Filologii Polskiej Wydziału Filologicznego na Uniwersytecie Wrocławskim. Jej zainteresowania obejmują genologię baśni, najnowsze zjawiska w przestrzeni kultury popularnej i pragmatyczny aspekt literatury dziecięcej. Kontakt: kamila.kowalczyk@uwr.edu.pl. 


\section{The Unknown Fate of a Well-Known Book: About Rediscovering Heinrich Hoffmann's Classic Work}

\section{Dybiec-Gajer, J. (2017). Złota różdżka - od książki dla dzieci po dreszczowiec raczej dla dorosłych. Kraków: Tertium.}

\section{Abstract:}

The review article discusses the book by Joanna Dybiec-Gajer, Złota różdzka - od książki dla dzieci po dreszczowiec raczej dla dorostych [A Golden Wand - from a Children's Book to a Thriller Rather for Adults] (2017). The text presents the structure, methodology, and the most important theses of the monograph on the already classic work by Heinrich Hoffmann (1845), as well as indicates the scholar's original and valuable findings proving the sense of rediscovering texts belonging to the cultural canon. The article points out also to the productivity of creating a microhistory of a literary work, taking into consideration numerous contexts of its functioning, and refers to Dybiec-Gajer's reflections on the ways of writing the text (including the structure, genre convention, adaptive mechanisms) and how to read it (including interpretation, reception), which is particularly interesting in the context of relations between the German Struwwelpeter and the Russian Stëpka-Rastrëpka (1849), or the Polish Złota różdzka [A Golden Wand] (ca. 1858).

\section{Key words:}

adaptation, critical-point analysis, Heinrich Hoffmann, Joanna Dybiec-Gajer, $19^{\text {th }}$-century literature, children's literature, German literature, translation, reception, Stëpka-Rastrëpka, Struwwelpeter, struwwelpetriades, Złota różdżka [A Golden Wand]

Mama wróciła, a Konrad płacze.

- Chodź no tu, synku, niech no zobaczę,

czy grzeczny byłeś, czy posłuchałeś,

czy też paznokcie znów obgryzałeś?

Przyznał się Konrad, że krawiec krwawy

rączki mu obciął za złe zabawy.

Obiecał zatem, blady jak trup,

że da też spokój paznokciom stóp

- przywołany fragment adaptacji pt. O Konradzie, co obgryzał paznokcie autorstwa Marcina Wróbla (2017, s. 74), wydanej w zbiorze Złota różḋ̇ka, czyli bajki dla niegrzecznych dzieci (Hoffmann, 2017) ${ }^{1}$, dowodzi wyraźnie, że XIX-wieczna tradycja - mimo nowego stroju i modernizacji treści - jest w swoisty sposób nadal żywa. Wzorcem dla wspomnianej publikacji jest książka-fenomen, istot-

1 Zob. także reprint trzeciego wydania petersburskiego (Hoffmann, 1892/2018). 
ne ogniwo w historii literatury dziecięcej (zarówno pod względem formalnym, jak i treściowym) oraz inspiracja dla późniejszych twórców - Struwwelpeter, opublikowany przez niemieckiego autora Heinricha Hoffmanna (1845).

W polskiej świadomości literackiej historie m.in. o Juleczku i jego obciętych przez krawca paluszkach czy Michasiu - niejadku, którego własna niechęć do jedzenia i grymaszenie prowadzą do zgonu, zakorzeniły się za sprawą rodzimego opracowania pt. Złota rószczka. Czytajcie dzieci, uczcie się, jak to niegrzecznym bywa źle ([Hoffmann], ok. 1858²). Polscy odbiorcy byli już w tym czasie zaznajomieni ze specyfiką moralizatorskich utworów, czego przykładem niezwykle popularne wiersze Stanisława Jachowicza, w których autor przedstawiał skutki dziecięcego nieposłuszeństwa spod znaku swawolnego Tadeuszka. Mimo że karty literatury przeznaczonej dla młodych odbiorców były już wówczas bogato zadrukowane postaciami dzieci krnąbrnych i niegrzecznych (Jonca, 2005), Struwwelpeter oferował nowy wymiar dziecięcych przewin i kar za nie wymierzanych. Dzieło w szczególny sposób łączyło w sobie grozę oraz absurdalny i groteskowy humor, było też atrakcyjną książką obrazkową (Dybiec-Gajer, 2018a).

Struwwelpetera przetłumaczono na ponad czterdzieści języków (w tym afrikaans i esperanto), a na jego podstawie powstawały zabawki, piosenki, przedstawienia, gry, komiksy i animacje (Dunin, 2003a, s. 134-135). Niezwykła popularność książki, która, jak się okazało, ma polimedialny potencjał i jest plastycznym materiałem dla autorskich adaptacji, przeróbek i parodii ${ }^{3}$, pozwoliła jej osiągnąć status dzieła klasycznego.

Utwór doczekał się licznych analiz, zestawień i interpretacji. Do najważniejszych należą prace Hermana Müllera (1975), Waltera Sauera (2003, 2015), Ute Liebert (b.d.), Elisabeth Wesseling (2004), Doris Wagner (2007), Barbary Smith Chalou (2007) czy Bena Parrota (2010). Książka Hoffmanna znalazła swoje miejsce także w polskojęzycznych opracowaniach naukowych, czego przykładem artykuły, analizy i szkice Janiny Wiercińskiej (1983, s. 291-296), Janusza Dunina (2003a; 2003b), Magdaleny Joncy (2002; 2005, s. 130-151; 2011), Katarzyny Slany (2016, s. 252-256) czy Agnieszki Gicali (2018), reprezentujące różne stanowiska i perspektywy badawcze.

2 Podana data ma charakter orientacyjny, za Dybiec-Gajer należy bowiem uznać, iż: „Rok 1858 przyjmuje się, za bibliografią K. Estreichera, za rok pierwszego wydania Złotej różdżki. Nie zachował się żaden egzemplarz tego wydania” (Dybiec-Gajer, 2017, s. 193).

3 By wspomnieć o takich reinterpretacjach jak Der Aegyptische Struwwelpeter (F. Netolitzky, R. Netolitzky, Kuzmany-Netolitzky, 1895) czy Struwwelhitler: A Nazi Story Book by Dr. Schrecklichkeit (R. Spence, P. Spence, 1941) i innych utworach nawiązujących do stylu oraz tematyki Hoffmannowskiego dzieła, tzw. struwwelpetriad. 
Z całą pewnością rodzimy stan wiedzy o Struwwelpeterze i o „dziejach kariery jednej książki” (Dunin 2003a) znacznie uzupełnia praca Joanny Dybiec-Gajer (2017), która udowadnia, że na temat XIX-wiecznej klasyki literackiej można jeszcze wiele napisać, uzupełniając luki i niedopowiedzenia w dotychczasowej refleksji nad przedmiotem badań. Złota różdżka - od książki dla dzieci po dreszczowiec raczej dla dorosłych stanowi przykład monografii niebanalnej, skoncentrowanej wokół jednego tekstu kultury i wielu warunkujących go kontekstów ${ }^{4}$.

Na uznanie zasługuje przemyślana i logiczna struktura publikacji, na którą składają się wstęp, trzy części zawierające przedruki tekstów literackich (m.in. utwór Hoffmanna w oryginale i polską adaptację), rozdział analityczny oraz zakończenie. Tak zaplanowany układ pozwala czytelnikowi stopniowo przyswajać treści, przekazywane zgrabnym i pełnym swady językiem. Materiały zgromadzone w publikacji oraz sposób ich prezentacji sprawiają, że Dybiec-Gajer oferuje odbiorcom monografię nietypową, o gatunkowo eklektycznej naturze, a przez to pod względem czytelniczym niezwykle atrakcyjną. Eliza Pieciul-Karmińska (2018, s. 384-385) słusznie zauważa, że w opracowaniu Dybiec-Gajer dostrzec można antologię tekstów, album czy kompendium - leksykon wiedzy.

Celem Dybiec-Gajer (2017) było prześledzenie oraz przeanalizowanie historii Struwwelpetera przy wykorzystaniu narzędzi z zakresu przekładoznawstwa. Formułując swoją propozycję badawczą, autorka podkreśla, że tekst stanowi przykład „[...] przekładu międzyjęzykowego i intersemiotycznego, kształtowanego przez zmieniające się kultury przekładowe" (s. 13). Badaczka jednak znacznie poszerza swoje pole badawcze, z pożytkiem dla monografii, prezentując rozwój i status analizowanego dzieła w kontekście historycznoliterackim i szerzej: kulturowym.

We Wstępie autorka przybliża informacje dotyczące historii i okoliczności powstania niemieckiego dzieła (co interesujące, Struwwelpeter wydany został jako książka bożonarodzeniowa) oraz jego filologicznych cech, uwzględniając także liczne przekłady utworu, a tym samym - jego międzynarodową karierę i złożoną recepcję. Dybiec-Gajer (2017) prezentuje również sylwetkę samego autora, zarysowując odbiorcom kontekst historyczny i kulturowy XIX-wiecznego Frankfurtu nad Menem. Badaczka sygnalizuje zawiłe losy Struwwelpetera w polskiej kulturze, dostrzegając, że historia ta jest „[...] niezwykle frapująca

4 Warto także odnotować, że Joanna Dybiec-Gajer (2018a) jest autorką hasła pt. Der Struwwelpeter oder lustige Geschichten und drollige Bilder für Kinder von 3-6 Jahren von Dr. Heinrich Hoffmann (1845), które pojawiło się w leksykonie poświęconym książce obrazkowej. Wyrazem naukowego zainteresowania Struwwelpeterem są również inne publikacje badaczki (Dybiec-Gajer, 2016, 2018b, 2018c). 
i umożliwia prawdziwe odkrycia. To fascynujący przykład podróży utworu poprzez różne kultury, języki i epoki, w której kluczową rolę odegrali pospołu wydawcy, tłumacze i ilustratorzy" (s. 12).

W pierwszej części (Złota różdżka. Czytajcie dzieci, uczcie się, jak to niegrzecznym bywa źle) autorka umieściła wiersze ze Złotej różḋ̇ki ${ }^{5}$, której autorstwo powszechnie przypisywane jest Wacławowi Szymanowskiemu. Do wersji tej dołączono pochodzące $\mathrm{z}$ drugiego manuskryptu ilustracje samego Hoffmanna (co interesujące, powstały one pod wpływem rosyjskiego wariantu, tj. Stiopki-Rastriopki; [Hoffmann], 1849) oraz uzupełniono je o tłumaczenia utworów pominiętych wcześniej przez polskiego autora. Jak twierdzi Dybiec-Gajer (2017): „Zaprezentowany tekst jest [...] pierwszym kompletnym polskim wydaniem Struwwelpetera z oryginalnymi ilustracjami autora" (s. 14).

W drugiej części (Pierwowzory Złotej różdżki) umieszczone zostały teksty z niemieckiego Struwwelpetera oraz rosyjskiej Stiopki-Rastriopki, dzięki którym, na zasadzie komparatystycznego zestawienia, dostrzec można podstawowe różnice między wydaniami oraz mechanizmy związane $\mathrm{z}$ adaptacją kulturową.

Część trzecia (Struwwelpetriady - wybrane teksty) zawiera unikatowe i rzadko spotykane w opracowaniach historycznoliterackich przeróbki i imitacje niemieckiego oryginału, tzw. struwwelpetriady (Dunin, 2003a, s. 134; Waksmund, 2000, s. 378). Autorka zamieściła w swojej publikacji przedruki utworów Kopciuszek dla grzecznych dzieci (Klonowski, 1868) oraz Stuchaj rodziców i starszych (b.a., ok. 1890) okraszone XIX-wiecznymi ilustracjami oraz niemieckimi tekstami, stanowiącymi ważne tło dla dalszych rozważań badaczki, a także zachętę do refleksji m.in. nad procesami zachodzącymi w literaturze dla dzieci sprzed dwóch wieków. W kontekście Kopciuszka..., co ważne, autorka dostrzega, że badacze często uznają ten utwór za pierwsze polskie tłumaczenie znanej baśni, co jest założeniem błędnym, wynikającym m.in. ze znajomości jedynie tytułu tekstu, a nie jego treści. Warto przy tym dostrzec, że Kopciuszek dla grzecznych dzieci nierzadko niesłusznie katalogowany jest także jako adaptacja/tłumaczenie baśni braci Grimmów (Pieciul-Karmińska, 2018, s. 386). Tego rodzaju rozważania pozwalają na rewizję dotychczas przyjętych ustaleń z zakresu historii literatury dziecięcej.

W części czwartej (Struwwelpeter - nowe życie w języku polskim) Dybiec-Gajer (2017), traktując Złotą różdżkę jako cymelium, w bardzo przystępnym

5 Wiersze są dopełniane przez przekłady dwóch utworów, które nie były drukowane w dotychczasowych polskich wydaniach (m.in. ze względu na tematyczne odbieganie od pozostałych tekstów), tj. prologu oraz historii o złym myśliwym. 
stylu opisuje historię wydań utworu w języku polskim, rekonstruując ewolucję i zawiłe ścieżki cyrkulacji dzieła w rodzimej kulturze. Autorka uwzględnia sprawę domniemanego autorstwa przekładu, za który miałby być odpowiedzialny Wacław Szymanowski, oraz wspomina o kwestii zapośredniczenia tłumaczenia Złotej różḋ̇ki przez „rosyjskiego antenata” (s. 106).

Badaczka $\mathrm{z}$ naukową pasją i dociekliwością opisuje kolejne interesujące oraz nieznane powszechnie fakty z zakresu kulturowego funkcjonowania Złotej różdżki. Co ważne, autorka wskazuje, że książka ta nie jest oryginalnym, rodzimym pomysłem, lecz - przede wszystkim - iż polski tekst wobec niemieckiego nie funkcjonuje na prawach przekładu właściwego, bowiem podstawą dla polskiej Złotej różdżki było przywołane wyżej rosyjskie tłumaczenie pt. Stiopka-Rastriopka. Rasskazy dla dietiej. Autorka rozwija również kwestię naśladowania i imitowania niemieckiego tekstu, wskazując na cechy, gatunki oraz przykłady struwwelpetriad, w tym także teksty polskie - badaczka przedstawia informacje nie tylko o wspomnianych już Kopciuszku... czy Stuchaj rodziców..., lecz także O Jasiu Dręczycielu, o Józiu Gapicielu, o Cesi Cmokosi i o spalonej Zosi pióra Artura Oppmana (ok. 1894), O łakomczuchu, niejadku i brudasku Zygmunta Wyrobka (ok. 1922) i Wesołej gromadce Bohdana Butenki (1987).

Bardzo interesującym zabiegiem zastosowanym przez Dybiec-Gajer jest uzupełnienie rozważań o rozmaite świadectwa odbioru Złotej różdżki. Autorka przywołuje wspomnienia m.in. Czesława Miłosza, Juliana Tuwima, Magdaleny Samozwaniec, Haliny Micińskiej-Kenarowej, opisując, jakie miejsce w ich doświadczeniu lekturowym zajmowały wiersze o niegrzecznych dzieciach. Prezentacja tego rodzaju treści pozwala na poruszenie problemu różnych form pamięci o jednym tekście oraz na dostrzeżenie jego kulturotwórczej roli i szerokiej skali interpretacyjnej. Należy przy tym zwrócić uwagę na potencjalną przydatność badań inspirowanych tzw. zwrotem afektywnym (Góralska, 2018) w kontekście badań konkretnych tekstów literackich.

W części czwartej znalazł się także obszerny podrozdział poświęcony metodologii badawczej zastosowanej przez autorkę, na którego odbiór mają wpływ bez wątpienia wcześniej wprowadzone źródła i materiały, przygotowujące niejako czytelnika do akademickiej eksplikacji. Dybiec-Gajer (2017, s. 138), przyjmując perspektywę przekładoznawczą, koncentruje się na metodzie poświęconej autorskiej analizie punktów krytycznych ${ }^{6}$. Taka strategia

6 „Jej celem jest ustalenie sieci strategicznie najistotniejszych cech i elementów tekstu wyjściowego, które wpływają na zrozumienie i recepcję tekstu, a następnie zbadanie, jakim zmianom podlegają one $\mathrm{w}$ procesie przeniesienia do nowej kultury. Metoda ta pozwala na uchwycenie w sposób całościowy i uporządkowany modyfikacji, jakim podlega tekst 
okazuje się niezwykle produktywna, ponieważ na podstawie przywoływanych i analizowanych przez badaczkę „punktów krytycznych” możliwe jest zrekonstruowanie warunków funkcjonowania tekstu w różnych kulturach, co jest szczególnie ważne w kontekście przekładu i jego „konsekwencji odbiorczej”, tj. rozumienia i recepcji. Dybiec-Gajer krok po kroku odkrywa Złota różdżkę, czyniąc to dzięki rozważaniom na temat ramy utworu, jego struktury czy amplifikacji wyróżniających wiersze w wersji polskiej (w tym kontekście niezwykle interesująca jest konstatacja dotycząca tego, iż morały z rodzimej wersji nie występują w wersji niemieckiej, co oczywiście znacząco wpływa na sposób odczytania polskiego tekstu) ${ }^{7}$. Co ważne, autorka opisuje również strategie charakterystyczne dla przekładu intersemiotycznego, przywołuje różne graficzne wcielenia Złotej różḋ̇ki, uwzględniając problem grupy odbiorczej tych tekstów, oraz nakreśla współczesne drogi rozwojowe dzieła.

W Zakończeniu Dybiec-Gajer (2017) potwierdza, że Struwwelpeter to swoisty kulturowy fenomen:

Dziewiętnastowieczny utwór o wiodącym przesłaniu edukacyjnym, ale i humorystycznym, trafił w połowie dwudziestego wieku do gabinetu osobliwości jako kuriozum minionej epoki, by w dwudziestym pierwszym wieku zostać odkrytym przez teatr i przez post-modernistyczną kulturę popularną. Nowe odsłony Złotej różdżki pokazują niezmierną żywotność utworu, który generuje różne możliwości odczytania i nie przestaje fascynować nawet współcześnie (s. 174).

Zbiorek Hoffmanna, stanowiący przykład książki autorskiej-doktórej pisarz sam wykonywał ilustracje - prezentuje utwory na swoje czasy oryginalne ze względu na nowatorski sposób eksploatowania wymiaru dydaktycznego (s. 140). Wywołał on ponadto falę tekstów naśladujących formułę analizowanych wierszy, tzn. już wspomnianych struwwelpetriad. Badaczka zaznacza, że Struwwelpeter wyznacza także „[...] początki książki obrazkowej dla dzieci i jest protoplastą komiksu” (s. 11; zob. także Cackowska, 2017, s. 14, 36-37; Wiercińska, 1983, s. 291-296). Stał

w przekładzie, ponieważ do jej założeń należy skupienie uwagi badawczej na kluczowych elementach tekstu, czyli punktach krytycznych" (Dybiec-Gajer, 2017, s. 138).

7 Z przekładoznawczą koncepcją autorki powiązać można działania mające na celu rekonstrukcję kontekstów kulturowych warunkujących tekst i wpływających jednocześnie na jego kształt w innych językach oraz kulturach. Jest to szczególnie ważne przy próbie zrozumienia problemów przekładalności tekstów kultury (w tym także możliwości ekwiwalencji przekładu) i przenoszenia językowego obrazu świata w nowe warunki językowo-kulturowe. O trudnościach związanych z przekładem literatury dla dzieci zob. Borodo, 2006; Niesporek-Szamburska, 2009; Albińska, 2009-2010; Dymel-Trzebiatowska, 2013; Szymańska, 2014; Zarych, 2016; Pieciul-Karmińska, Sommerfeld, Fimiak-Chwiłkowska, 2017. 
się również ważnym ogniwem w historii międzynarodowego prawa autorskiego (Dybiec-Gajer, 2018c, s. 331). Historie o niegrzecznych dzieciach realizujące schemat znany z tzw. powiastek ku przestrodze, tj. grzech/wykroczenie - kara (Czernow, 2013, s. 54; zob. także Tatar, 1987, s. 191-192), fantastyczne postaci i zapadające w pamięć rymy okazały się na tyle atrakcyjne i interesujące z perspektywy odbiorczej, że z łatwością zakorzeniły się w kulturze popularnej, a nawet w mowie codziennej (w kulturze niemieckiej używa się np. imion bohaterów na określenie konkretnych zachowań i cech: Suppenkaspar - 'niejadek' czy Zappelphilipp - 'wiercipięta'; Dybiec-Gajer, 2017, s. 12). O fenomenie Struwwelpetera zaświadczają również rozmaite sposoby jego interpretacji i świadectwa odbioru - dzieło przebyło symboliczną (ale i krętą pod względem interpretacyjnym) drogę: od tekstu skandalizującego, represyjnego i reprezentującego nurt „czarnej pedagogiki” (Slany, 2016, s. 249) po tekst jawnie ludyczny oraz służący zabawie okraszonej nutą absurdu i purnonsensu.

O wpływie wierszy Hoffmanna na dzieci pisano wielokrotnie, uwzględniając nierzadko status i wymiar kar prezentowanych w poszczególnych utworach, a w konsekwencji ich grozotwórczy potencjał. Jonca (2005) dostrzega, że „[...] przewinienia dzieci grzeszących niejedzeniem, ssaniem palca czy gapiostwem, napotykają tu niewyobrażalną wprost surowość, a rodzaj kar, jakie tu na nie spadają, świadczyłyby raczej, że autor miał do czynienia z prawdziwymi przestępcami” (s. 130; zob. także Slany, 2016, s. 255). Waksmund (2000), zajmując nieco inne stanowisko, pisał, iż „[...] skandaliczna treść miała dla małoletnich czytelników o wiele większe znaczenie niż nauka moralna, jaką można było doczepić do każdej tzw. budującej historii” (s. 378). Owa „skandaliczna treść" byłaby więc po prostu atrakcyjna i pożądana przez odbiorców - niejednokrotnie już przecież teksty kultury udowodniły, że zawarta w nich groza i fantastyka po prostu fascynują.

Spojrzenie na niemieckie dzieło z szerszej perspektywy postulował Janusz Dunin (2003b), dostrzegając potrzebę przeanalizowania zarówno formy samej publikacji, jak i problemu wielowymiarowości dominanty estetycznej Hoffmannowskich tekstów:

Aby zrozumieć sens i znaczenie pracy Heinricha Hoffmanna, trzeba [...] oderwać się od odczuć grozy czy też tylko komizmu tekstów. Pozycja zdobyła świat, trzeba więc spojrzeć na nią z nieco szerszej perspektywy, roli, jaką odegrała w dziejach rozwoju literatury i publikacji dla dzieci. Osadzona była w tradycjach ówczesnej literatury dydaktycznej i praktyki wychowania preferującego od lat stosowanie wobec malców srogich kar. Nowością pomysłów niemieckiego lekarza było nie tylko wprowadzenie lub rozpowszechnienie formuły książki dla najmłodszych, 
tworzącej na kartach montaż obrazów i tekstów, który trwa w publikacjach dziecięcych do dziś i wydaje się dostatecznie trwały. Ważne i nowe było też potraktowanie tematu humorystycznie, dziś powiedzielibyśmy z przymrużeniem oka. Wbrew temu, co dziś możemy sądzić, teksty nie brały opisywanych kar dostatecznie serio, $\mathrm{w}$ istocie nie chciały straszyć dzieci a bawić. W tym sensie znaczna część przyszłej literatury dziecięcej, wraz z Tuwimem i Brzechwą, stanowiła kontynuację myśli Hoffmanna, który przeciwstawił się niesłychanie solennemu tonowi dydaktycznemu wcześniejszej literatury dla małego odbiorcy (s. 26).

W kontekście zarysowanych rozważań na szczególną uwagę zasługuje więc część pracy, w której Dybiec-Gajer (2017) zastanawia się właśnie nad estetyczno-gatunkową dominantą utworu oraz możliwymi sposobami jego interpretacji:

Wiersze ze zbioru Hoffmanna, chociaż czerpały inspiracje z wcześniejszych utworów, zwłaszcza na tle współczesnej twórczości dla dzieci były frapujące i zaskakujące, budowały napięcie między elementami horroru a humorem. Wydaje się jednak, że na pierwszym planie jako środek dotarcia do czytelnika znajdował się humor. Sam autor określił swoje historyjki i towarzyszące im ilustracje jako ucieszne. Efekty humorystyczne wykorzystane są w różnoraki sposób: poprzez konstrukcję utworu na zasadzie hiperboli i odwróceniu normalnego, tradycyjnego świata; za pomocą środków językowych (rymy, onomatopeje) oraz poprzez szatę graficzną, na którą składają się naiwno-groteskowe rysunki skonstruowane w sposób zapowiadający komiks (s. 140).

Autorka, podążając do pewnego stopnia linią interpretacyjną wyznaczoną przez Dunina i wychodząc jednocześnie poza dość klasyczne już w tym momencie odczytania Struwwelpetera przez pryzmat jego brutalnych treści, wskazuje, że konwencja humorystyczna może być właśnie tą, która strukturyzuje poszczególne wiersze Hoffmanna. Z taką propozycją interpretacji tekstu wiążą się kolejne ważne kwestie rzutujące w konsekwencji na model lektury analizowanego dzieła.

Literatura niemiecka nierzadko w rozmaitych świadectwach odbioru oraz analizach prezentowana jest jako „okrutna”, „drastyczna” i „wypaczająca sumienia”, czego doskonałym przykładem losy baśni braci Grimmów w kulturze polskiej oraz wyrosła wokół nich czarna legenda:

W polskojęzycznej recepcji utrwalił się i rozpowszechnił pogląd o »niemieckim okrucieństwie« w literaturze dla dzieci. Tymczasem krytyczne analizy translatoryczne pokazują, że polski czytelnik (a nierzadko i badacz) formułuje takie opinie w oparciu o rodzime przekłady, które te ponure wątki wzmacniają lub wręcz dopisują. Przypomina to klasyczną projekcję psychologiczną: polski czytelnik 
(badacz) krytykuje niemieckiego autora za okrucieństwo bądź wymóg posłuszeństwa i oskarża (niemiecki) oryginał o coś, co do tekstu wprowadziła polska tradycja. Tymczasem to polski przekład jest bardziej okrutny i moralizatorski od oryginału. Można wręcz odnieść wrażenie, że badania nad recepcją literatury niemieckojęzycznej więcej mówią nam o nas samych niż o tekstach oryginalnych (Pieciul-Karmińska, 2018, s. 393; zob. także Dunin, 2003a, s. 142).

Struwweltpeter także nie uniknął skojarzeń z niezwykłą brutalnością, sadyzmem i nieadekwatnością wymierzanych dzieciom kar - asocjacji stereotypizujących dzieło i osadzających je w konkretnej praktyce interpretacyjnej. Dybiec-Gajer (2017, s. 150; zob. także 2018c, s. 338) wskazuje jednak, że wyraziste i okrutne morały, które kończą wiersze w polskiej Złotej różdżce, nie występują w wersji niemieckiej. Ponadto, w wersji polskiej zrezygnowano z podtytułu, akcentującego humorystyczny i zabawowy wymiar tekstów oraz dookreślającego grupę docelowych odbiorców: Lustige Geschichten und drollige Bilder mit 15 schön kolorierten Tafeln für Kinder von 3-6 Jahren [Wesołe historie i ucieszne obrazki z 15 pięknie kolorowanymi kartami dla dzieci od lat 3 do 6]. Rodzima propozycja tytułu odwołuje się zaś do tradycji wymierzania kar nieposłusznym dzieciom za pomocą rózgi ${ }^{8}$, co wzmacnia moralizatorsko-dydaktyczny wymiar tekstu - to wszystko zmienia zatem znaczenie oryginalnego dzieła.

Jeszcze inną perspektywę interpretacyjną wyznacza autorka, przedstawiając sens i powód takiego, a nie innego kształtu Hoffmannowskich historii:

Historyjki przedstawiają przede wszystkim reguły dotyczące elementarnych zasad funkcjonowania człowieka w świecie, w tym zachowań, które warunkują życie i przeżycie. Wiersz o płonącej dziewczynce powstał jako odpowiedź na pojawiające się nowe źródła niebezpieczeństw dla dzieci, jakim w tym przypadku były zapałki, produkowane od 1834 r. w nieodległym od Frankfurtu Darmstadt (Dybiec-Gajer, 2017, s. 140).

Rekonstrukcja kulturowych kontekstów funkcjonowania tekstu, przypominająca krótkimi momentami Darntonowskie (1984/2012) pisanie o epizodach francuskiej historii kulturowej, okazuje się niezwykle produktywna. Strategia

8 Nieodłącznym elementem historii dzieciństwa była rózga, której wykorzystanie w procesie wychowania dziecka, przy jednoczesnej dbałości czy to o jego duszę, czy moralność, wskazywali m.in. Andrzej Frycz Modrzewski, Ignacy Krasicki czy Władysław Bełza (Jonca, 2005, s. 11, 17-53, 359-398). W Polsce już pod koniec XVIII wieku znany był wierszyk, w którym rózdze nadawano wysoką rangę w procesie wychowawczym, by wspomnieć fragment następujący: „Różdżką Duch Święty dziateczki bić radzi / Różdżka bynajmniej zdrowiu nie zawadzi" (cyt. za: Jonca, 2005, s. 18). 
ta ułatwia zrozumienie procesu historycznoliterackiego (łatwiej przy tym ustrzec się ahistoryzmu); uzmysławia też, iż tekst nie funkcjonuje w próżni, i otwiera nowe pola interpretacyjne dla badaczy.

Metoda swoistych „drobiazgowych analiz” (czy też swego rodzaju „filologiczna indukcja"), którą dostrzec można w rozważaniach autorki m.in. nad tłumaczeniem zapośredniczonym oraz rekonstrukcją kontekstów warunkujących taki, a nie inny kształt tekstu, może stać się istotnym punktem metodologicznego wyjścia dla badaczy zajmujących się kulturową obecnością utworów uznanych za klasyczne. Wspomnieć tu można o dziełach sygnowanych nazwiskami Wilhelma i Jakuba Grimmów, Lewisa Carrolla, Charlesa Dickensa, Hansa Christiana Andersena, E. T. A. Hoffmanna, Frances Hodgson Burnett czy Rudyarda Kiplinga. Oczywiście, otwiera to również ścieżkę do drobiazgowej analizy tekstów zapomnianych lub mniej rozpoznawalnych.

Przemyślana metodologia oraz struktura publikacji świadczą nie tylko o naukowym zaangażowaniu autorki, lecz także o jej dbałości o czytelników, czego doskonałym przykładem są reprinty i oryginalne materiały źródłowe, które znacznie ułatwiają odbiorcom partycypację w kolejnych analizach o charakterze komparatystycznym. Monografia ma bowiem trudne do przecenienia walory estetyczne, przygotowana została $\mathrm{z}$ dużą dbałością edytorską, $\mathrm{w}$ większym formacie i twardej oprawie, przy użyciu dobrej jakości papieru. Kolejne strony wypełniają zarówno reprinty analizowanych tekstów źródłowych, jak i szereg grafik, ilustracji, monogramów, portretów, litografii. Nie tylko stanowią one atrakcyjny wizualnie dodatek, lecz także uzupełniają rozważania badaczki oraz konkretyzują kulturowe konteksty funkcjonowania dzieła.

Wykorzystana przez autorkę metodologia, rzetelnie dobrane źródła tekstowe oraz ikonograficzne, ciekawie zarysowana historia wydawnicza dzieła, liczne jego adaptacje i świadectwa odbioru, a także niezwykle interesujące i poszerzające zakres wiedzy materiały dodatkowe ${ }^{9}$ sprawiają, że cel, jaki postawiła sobie badaczka, tj. stworzenie „[...] kompendium wiedzy o polskich losach Struwwelpetera" (Dybiec-Gajer, 2017, s. 14), zostaje w pełni osiągnięty, przynosząc satysfakcję czytelniczą. Ze względu na swoją formułę książka ma szeroki adres odbiorczy: może zainteresować badaczy akademickich (np. litera-

9 Rozważania badaczki uzupełniają m.in. bibliografa, kalendarium związane z powstaniem książki Der Struwwelpeter i jej polską historią, zestawienie tytułów wierszy z polskojęzycznych wydań Struwwelpetera i jego naśladownictw z pierwowzorami, bibliograficzne zestawienie polskich struwwelpetriad wraz z komentarzem, rozmowy z autorkami ilustracji do współczesnych wydań Złotej różḋ̇ki, a nawet przedruki znaczków pocztowych, na których znalazły się postaci z wierszy Hoffmanna. 
turoznawców, kulturoznawców, przekładoznawców, pedagogów, historyków), tłumaczy oraz wszystkich zainteresowanych literaturą dla dzieci i ciekawymi „kulturowymi przypadkami” w jej historii.

Publikacja Joanny Dybiec-Gajer, która w przystępny sposób popularyzuje wiedzę o losach Złotej różdżki, to w moim przekonaniu modelowa analiza realizująca cel zrekonstruowania mikrohistorii wybranego tekstu kultury przy uwzględnieniu jego swoistej filogenezy oraz kontekstu kulturowego warunkującego sposób zarówno pisania dzieła, jak i jego czytania.

\section{Bibliografia}

Albińska, K. (2009-2010). „Tylko to, co najlepsze, jest dość dobre dla dzieci”, czyli o dylematach tłumacza literatury dziecięcej. Przekładaniec, 22-23(2-1), 259-282.

b.a. Stuchaj rodziców i starszych, książeczka obrazkowa o niegrzecznych dzieciach (ok. 1890). Cieszyn: Edward Feitzinger.

Borodo, M. (2006). Children's literature translation studies? - zarys badań nad literaturą dziecięcą w przekładzie. Przekładaniec, 16(1), 12-23.

Butenko, B. (1987). Wesoła gromadka. Wybór poemacików i fotografii oraz ręczne zdobienie Bohdan Butenko. Warszawa: Młodzieżowa Agencja Wydawnicza.

Cackowska, M. (2017). Współczesna książka obrazkowa - pojęcie, typologia, badania, teorie, konteksty, dyskursy. W: M. Cackowska, H. Dymel-Trzebiatowska, J. Szyłak (red.), Książa obrazkowa. Wprowadzenie (s. 11-48). Poznań: Instytut Kultury Popularnej.

Chalou Smith, B. (2007). Struwwelpeter: Humor or horror? 160 years later. Lanham, MD, Boulder, CO, New York, NY, Toronto, Plymouth: Lexington Books.

Czernow, A. M. (2013). Uparte dzieci Maryi. Dydaktyzm w baśniach braci Grimm. W: W. Kostecka (red.), Grimm: potęga dwóch braci. Kulturowe konteksty Kinderund Hausmärchen (s. 49-64). Warszawa: Oficyna Wydawnicza ASPRA-JR.

Darnton, R. (2004). Chłopi opowiadają bajki. Wymowa Bajek Babci Gąski W: Wielka masakra kotów i inne epizody francuskiej historii kulturowej (D. Guzowska, tłum., s. 23-91). Warszawa: WN PWN. (wyd. oryg. 1984).

Dunin, J. (2003a). Struwwelpeter, czyli Złota różdżka. Z dziejów kariery jednej książki. Literatura i Kultura Popularna, 11, 133-144.

Dunin, J. (2003b). Struwwelpeter, Stepka-Rastrepka czyli Złota Różdżka - z dziejów kariery jednej książki. W: H. Hoffmann, Złota różdżka. Reedycja petersburskiego wydania z roku 1883 (s. 4-43). Łódź: Verso.

Dybiec-Gajer, J. (2016). Wiersze dla dzieci w przekładzie profesjonalnym i amatorskim - „Der Wilde Jäger” ze zbioru Struwwelpeter (Złota różdżka) po polsku. Orbis Linguarum, 48, 225-246. 
Dybiec-Gajer, J. (2017). Złota różdżka - od książki dla dzieci po dreszczowiec raczej dla dorosłych. Kraków: Tertium.

Dybiec-Gajer, J. (2018a). Der Struwwelpeter oder lustige Geschichten und drollige Bilder für Kinder von 3-6 Jahren von Dr. Heinrich Hoffmann (1845). W: M. Cackowska, H. Dymel-Trzebiatowska, J. Szyłak (red.), Ksiażka obrazkowa. Leksykon. Tom 1 (s. 27-35). Poznań: Instytut Kultury Popularnej.

Dybiec-Gajer, J. (2018b). Implikacje utożsamiania przekładu z oryginałem. Polemika z interpretacją Złotej różdżki w książce Katarzyny Slany Groza w literaturze dziecięcej. Od Grimmów do Gaimana, Kraków 2016, 330 stron. Rocznik Przekładoznawczy, 13, 287-296. https://doi.org/10.12775/RP.2018.017.

Dybiec-Gajer, J. (2018c). Lokalizacja a przekład dla dzieci. Jak utwory strasznieją i mądrzeją w tłumaczeniu na przykładzie Stasia Straszydło i Mądrej Myszy. W: A. Knapik, P. Chruszczewski (red.), Między tekstem a kulturą. Z zagadnień przekładoznawstwa (s. 323-345). San Diego, CA: Æ Academic Publishing.

Dymel-Trzebiatowska, H. (2013). Translatoryka literatury dziecięcej. Analiza przekładu utworów Astrid Lindgren na język polski. Gdańsk: Wydawnictwo UG.

Gicala, A. (2018). Przekład obrazka i obrazu świata - najnowsze polskie tłumaczenia Struwwelpetera Heinricha Hoffmanna. Orbis Linguarum, 48, 273-287.

Góralska, M. (2018). Zwrot afektywny a współczesne badania nad książką i czytelnikiem. Rekonesans badawczy. Przegląd Biblioteczny, 86(2), 220-232. https://doi. org/10.36702/pb.431.

Hoffmann, H. (1845). Der Struwwelpeter oder lustige Geschichten und drollige Bilder für Kinder von 3-6 Jahren von Dr. Heinrich Hoffmann. Frankfurt am Main: Literarische Anstalt.

[Hoffmann, H.]. (1849). Stiopka-Rastriopka. Rasskazy dla dietiej (b.t.). Petersburg: b.w. [Hoffmann, H.]. (ok. 1858). Złota rószczka. Czytajcie dzieci, uczcie się, jak to niegrzecznym bywa źle (prawdop. W. Szymanowski, adapt.). Petersburg: M. B. Wolff.

Hoffmann, H. (2017). Złota różdżka, czyli bajki dla niegrzecznych dzieci (Z. Naczyńska, A. Bańkowska, K. Iwaszkiewicz, A. Pluszka, M. Rusinek, adapt.). Warszawa: Egmont Polska.

Hoffmann, H. (2018). Złota rószczka. Czytajcie dzieci, uczcie się, jak to niegrzecznym bywa źle. Wydanie trzecie (W. Szymanowski, tłum.). Warszawa: Graf_ika. (wyd. oryg. 1892).

Jonca, M. (2002). „Kto nie chce zupy, ten umrzeć musi...” - pedagogika strachu, czyli śmierć za karę. W: J. Kolbuszewski (red.), Problemy współczesnej tanatologii. Medycyna - antropologia kultury - humanistyka (t. 6, s. 333-339). Wrocław: Wrocławskie Towarzystwo Naukowe.

Jonca, M. (2005). Enfants terribles. Dzieci złe, źle wychowane w literaturze polskiej XIX wieku. Wrocław: Wydawnictwo UWr.

Jonca, M. (2011). Historia o Stasiu Straszydle i innych rozrabiakach (Heinrich Hoffmann: Złota rożdżka). W: E. Białek, G. Kowal (red.), Arcydzieła literatury 
niemieckojęzycznej. Szkice, komentarze, interpretacje (t. 2, s. 9-20). Wrocław: Oficyna Wydawnicza Atut.

Klonowski, T. (1868). Kopciuszek dla grzecznych dzieci. Poznań: J. Jołowicz.

Liebert, U. (b.d.). Der Struwwelpeter. Bibliographie und Buchgeschichte des Kinderbuchklassikers Der Struwwelpeter und aller späteren Bilderbücher des Frankfurter Arztes Dr. Heinrich Hoffmann. Osnabrück: H. Th. Werner. Pobrane z: http://www. wenner.net/werke/liebert.htm.

Müller, H. (1973). Struwwelpeter und Struwwelpetriaden. W: H. Müller, K. Doderer (red.), Das Bilderbuch. Geschichte und Entwicklung des Bilderbuchs in Deutschland von den Anfängen bis zur Gegenwart (s. 141-182). Weinheim: Beltz.

Netolitzky, F., Netolitzky, R., Kuzmany-Netolitzky, M. (1895). Der Aegyptische Struwwelpeter. Vienna: Carl Gerolds Sohn.

Niesporek-Szamburska, B. (2009). Przekłady literatury dla dzieci i młodzieży - między przekazem wielokulturowym a zunifikowanym. W: K. Heska-Kwaśniewicz (red.), Literatura dla dzieci i młodzieży (po roku 1980). T. 2 (s. 46-71). Katowice: Wydawnictwo UŚ.

Oppman, A. (ok. 1894). O Jasiu Dręczycielu, o Józiu Gapicielu, o Cesi Cmokosi i o spalonej Zosi. Warszawa: Michał Arct.

Parrot, B. (2010). Aesthetic tension: The text-image relationship in Heinrich Hoffmann's Struwwelpeter. Monatshefte, 102(3), 326-339.

Pieciul-Karmińska, E. (2018). O niektórych aspektach tradycji czytania i przekładania literatury dla dzieci. Na kanwie recenzji książki Joanny Dybiec-Gajer, Złota Różdżka - od książki dla dzieci po dreszczowiec raczej dla doroslych. Porównania, 22(1), 383-397. https://doi.org/10.14746/por.2018.1.22.

Pieciul-Karmińska, E., Sommerfeld, B., Fimiak-Chwiłkowska, A. (2017). Między manipulacja a autonomicznościa estetyczna - przekład literatury dla dzieci. Poznań: WN UAM.

Sauer, W. (2003). A classic is born: The "childhood” of Struwwelpeter. The Papers of the Bibliographical Society of America, 97(2), 215-263.

Sauer, W. (2015). Der Struwwelpeter und sein Schöpfer Dr. Heinrich Hoffmann. Bibliographie der Sekundärliteratur. Neckarsteinach: Tintenfaß.

Slany, K. (2016). Groza w literaturze dziecięcej. Od Grimmów do Gaimana. Kraków: WN UP.

Spence, R., Spence, P. (1984). Struwwelhitler: A nazi story book by Dr. Schrecklichkeit. London: Haycock.

Szymańska, I. (2014). Przekłady polemiczne w literaturze dziecięcej. Rocznik Przekładoznawczy, 9, 193-208.

Wagner, D. (2007). Der Struwwelpeter. Das bekannteste Kinderbuch der Welt. Eine kurze Rezeptionsgeschichte dieses alten deutschen Kulturguts. Neuphilologische Mitteilungen, 108(4), 641-657. 
Tatar, M. (1987). The hard facts of the Grimms' fairy tales. Princeton: Princeton University Press.

Waksmund, R. (2000). Od literatury dla dzieci do literatury dziecięcej (tematy - gatun$k i-k o n t e k s t y)$. Wrocław: Wydawnictwo UWr.

Wesseling, E. (2004). Visual narrativity in the picture book: Heinrich Hoffmann's Der Struwwelpeter. Children's Literature in Education, 35(4), 319-345. https://doi. org/10.1007/s10583-004-6416-z.

Wiercińska, J. (1983). Książka obrazkowa - tradycja i współczesność. W: J. Cieślikowski, R. Waksmund (red.), Literatura i podkultura dzieci i młodzieży. Antologia opracowań (s. 286-308). Wrocław: Wydawnictwo UWr.

Wróbel, M. (2017). O Konradzie, co obgryzał paznokcie. W: H. Hoffmann, Złota różdżka, czyli bajki dla niegrzecznych dzieci (Z. Naczyńska, A. Bańkowska, K. Iwaszkiewicz, A. Pluszka, M. Wróbel, M. Rusinek, adapt., s. 66-75). Warszawa: Egmont Polska.

Wyrobek, Z. (ok. 1922). O łakomczuchu, niejadce i brudasku. Poznań: Księgarnia Św. Wojciecha.

Zarych, E. (2016). Przekład literatury dla dzieci i młodzieży - między tekstem a oczekiwaniami wydawcy i czytelnika. Teksty Drugie, 1, 206-227. https://doi.org/10.18318/ $\underline{\text { td.2016.1.13. }}$. 